\title{
Analisis kesulitan menyelesaikan soal model ujian nasional matematika dan self-efficacy siswa SMA
}

\author{
Maria Rosadalima Wasida ${ }^{1}$, H. Hartono ${ }^{1}$ \\ ${ }^{1}$ Program Studi Pendidikan Matematika, Program Pascasarjana, Universitas Negeri Yogyakarta. \\ Jalan Colombo No. 1, Karangmalang, Yogyakarta 55281, Indonesia. \\ * Corresponding Author. Email: maria.r.wasida@gmail.com \\ Received: 18 July 2016; Revised: 26 February 2018; Accepted: 30 April 2018
}

\begin{abstract}
Abstrak
Tujuan penelitian ini adalah mendeskripsikan jenis, letak, faktor kesulitan menyelesaikan soal model Ujian Nasional matematika dan self-efficacy siswa SMA di Kabupaten Ngada. Penelitian ini termasuk penelitian survei dengan pendekatan kuantitatif dan kualitatif. Subjek penelitian sebanyak 95 siswa SMA di Kabupaten Ngada, berasal dari empat sekolah dengan kategori tinggi, sedang dan rendah. Pengumpulan data menggunakan tes diagnostik, angket, observasi, dan pedoman wawancara. Tes diagnostik terdiri atas 7 butir soal uraian yang merupakan soal dengan daya serap rendah berdasarkan hasil UN tahun pelajaran 2014/2015 untuk mendiagnosis jenis dan letak kesulitan. Analisis data dilakukan dengan menghitung persentase jenis dan letak kesulitan, serta tingkat selfefficacy siswa. Hasil penelitian menunjukkan bahwa jenis kesulitan yang dialami siswa dalam menyelesaikan soal model Ujian Nasional matematika yaitu menyatakan fakta $(79,5 \%)$, memahami konsep (88,7\%), menerapkan prinsip (93,5\%), dan menerapkan keterampilan $(92,9 \%)$. Kesulitan siswa terletak pada menentukan apa yang diketahui $(77,3 \%)$, apa yang ditanya $(44,4 \%)$, rumus $(71,6 \%)$, sistematika penyelesaian (83\%), hubungan antar konsep (92\%), hubungan fakta dan konsep (89\%), jawaban akhir (91,9\%), dan menyelesaikan operasi dasar matematika (88,9\%). Faktor-faktor penyebab kesulitan yang dialami siswa dalam menyelesaikan soal model Ujian Nasional matematika antara lain ketidakmampuan dalam operasi aljabar, lupa, kurang teliti, terburu-buru, cepat menyerah, waktu yang kurang, kurangnya kesiapan dan keaktifan siswa, ketidakefektifan metode pembelajaran dan peranan guru. Self-efficacy dari 95 siswa siswa berada pada kriteria sedang.
\end{abstract}

Kata Kunci: analisis kesulitan, self-efficacy, ujian nasional

\section{An analysis of the difficulty in solving mathematic problem national examination model and self-efficacy of students of SHSs}

\begin{abstract}
This study aims to describe types, loci, and factors of the difficulty in solving mathematic problem national examination model and self-efficacy of students of senior high schools (SHSs) in Ngada Regency. This was a survey study using the quantitative and qualitative approaches. The research subjects were 95 students of SHSs in Ngada Regency from four schools with high, moderate, and low categories. The data were collected from diagnostic test, questionnaire, observation, and interview guideline. A diagnostic test consisting of 7 essay test items with low absorption indices according to the results of the NEs in the academic year of 2014/2015 to trace the types and the loci of difficulties. Data analysis was performed by calculating the percentage of the type and the loci of difficulties, and level of self-efficacy. The results showed that the type of difficulty experienced by students in solving the problem of the National Exam model of mathematics in expressing facts (79.5\%), understanding concepts (88.7\%), applying principle of (93.5\%), and applying skills (92.9\%). The loci of difficulties on determining the known (77.3\%), determining the asked (44.4\%), determining formulas (71.6\%), determining solution systems (83\%), determining the relationships among concepts (92\%), determining the relationships between facts and concepts (89\%), determining final answers (91.9\%), and the difficulty in solving basic mathematical operations $88,9 \%$. The factors underlying the difficulties are the inability in algebra operations, forgotten, less conscientious, are in a hurry, give up easily, the time is not enough, lack of the readiness and the involvement of student,
\end{abstract}


Jurnal Riset Pendidikan Matematika, 5 (1), 2018 - 83

Maria Rosadalima Wasida, H. Hartono

the ineffective of teaching methods and the teacher role. The self-efficacy of 95 students is at moderate criteria.

Keywords: analysis of difficulties, self-efficacy, national examination

How to Cite: Wasida, M., \& Hartono, H. (2018). Analisis kesulitan menyelesaikan soal model ujian nasional matematika dan self-efficacy siswa SMA. Jurnal Riset Pendidikan Matematika, 5(1), 82-95.

doi:http://dx.doi.org/10.21831/jrpm.v5i1.10060

Permalink/DOI: http://dx.doi.org/10.21831/jrpm.v5i1.10060

\section{PENDAHULUAN}

Matematika merupakan salah satu mata pelajaran yang sangat penting untuk dipelajari siswa. Dengan mempelajari matematika, siswa akan belajar berpikir secara kritis dan kreatif serta memiliki kesempatan untuk membekali diri dalam membentuk masa depan mereka. Dalam Permendikbud Nomor 59 Tahun 2014 tentang Kurikulum 2013 SMA/MA disebutkan bahwa matematika merupakan ilmu universal yang berguna bagi kehidupan manusia dan juga mendasari perkembangan teknologi modern, serta mempunyai peran penting dalam berbagai disiplin ilmu dan memajukan daya pikir manusia (Menteri Pendidikan dan Kebudayaan Republik Indonesia, 2014). Kompetensi matematika membuka pintu untuk masa depan yang produktif (National Council of Teacher Mathematics, 2000, p. 5).

Peranan matematika dalam pendidikan tidak terlepas dari upaya pemerintah dalam memperbaiki kualitas pendidikan melalui evaluasi pendidikan. Salah satu bentuk evaluasi pada setiap jenjang pendidikan formal yang diselenggarakan pemerintah adalah Ujian Nasional. Dalam Permendikbud Nomor 66 Tahun 2013 tentang Standar Penilaian Pendidikan, dijelaskan bahwa Ujian Nasional yang selanjutnya disebut UN merupakan kegiatan pengukuran kompetensi tertentu yang dicapai peserta didik dalam rangka menilai pencapaian Standar Nasional Pendidikan, yang dilaksanakan secara nasional (Menteri Pendidikan dan Kebudayaan Republik Indonesia, 2013). Hasil Ujian Nasional dapat dijadikan masukan terhadap perbaikan proses pembelajaran di satuan pendidikan atau sekolah, harapan terhadap UN adalah mendorong pendidik untuk selalu menyempurnakan strategi pembelajaran yang digunakan di kelas (Mardapi, 2017, p. 223).

Kabupaten Ngada merupakan salah satu kabupaten yang terletak di Provinsi Nusa Tenggara Timur. Berdasarkan laporan hasil UN oleh BSNP, rata-rata nilai matematika pada Ujian Nasional SMA program IPA, IPS, Bahasa, dan
Agama dari tahun pelajaran 2012/2013 sampai dengan 2014/2015 di Kabupaten Ngada masih rendah, bahkan dalam setiap tahun pelajaran tidak ada rata-rata nilai matematika yang memenuhi kriteria ketuntasan minimal $(\mathrm{KKM}=$ 65). Selain itu, rata-rata nilai matematika pada Ujian Nasional di Kabupaten Ngada cenderung menurun dari tahun ke tahun. Rata-rata nilai matematika pada Ujian Nasional SMA di Kabupaten Ngada selama tiga tahun terakhir disajikan pada Tabel 1.

Tabel 1. Rata-rata Nilai Matematika pada Ujian Nasional SMA di Kabupaten Ngada

\begin{tabular}{ccccc}
\hline Tahun & \multicolumn{4}{c}{ Program } \\
\cline { 2 - 5 } Pelajaran & IPA & IPS & Bahasa & Agama \\
\hline $2012 / 2013$ & 44,7 & 44,4 & 44,1 & 37,1 \\
$2013 / 2014$ & 34,6 & 39,4 & 40,7 & 25,4 \\
$2014 / 2015$ & 29,5 & 33,0 & 29,3 & 23,2 \\
\hline
\end{tabular}

Sumber: Pamer BSNP

Selain rata-rata nilai matematika yang rendah, persentase daya serap siswa untuk setiap kompetensi matematika yang diujikan pada tahun pelajaran 2012/2013, 2013/2014 dan 2014/2015 juga belum mencapai 65\%. Dalam penelitian ini persentase daya serap yang dimaksud adalah persentase daya serap pada program IPA. Pada tahun pelajaran 2014/2015, untuk program IPA terdapat beberapa kompetensi yang memiliki daya serap rendah yaitu: (1) Menentukan persamaan lingkaran atau garis singgung lingkaran, (2) Menghitung ukuran pemusatan atau ukuran letak dari data dalam bentuk tabel, diagram atau grafik, (3) Menyelesaikan masalah sehari-hari dengan menggunakan kaidah pencacahan, permutasi atau kombinasi, (4) Menyelesaikan masalah yang berkaitan dengan peluang suatu kejadian, dan (5) Menyelesaikan masalah yang berkaitan dengan nilai perbandingan trigonometri yang menggunakan rumus jumlah dan selisish sinus, cosinus dan tangen serta jumlah dan selisih dua sudut. Daya serap dari kelima kompetensi tersebut secara berturut-turut sebesar 30,13\%; $38,44 \%$; 40,26\%; $19,22 \%$; dan 19,48\%. 
Rendahnya rata-rata nilai dan persentase daya serap siswa untuk setiap kompetensi yang diujikan menunjukkan bahwa siswa mengalami kesulitan dalam menyelesaikan soal-soal UN. Selain itu, keyakinan siswa (self-efficacy) akan kemampuannya dalam menyelesaikan soal-soal UN juga turut mempengaruhi keberhasilan siswa dalam pencapaian hasil belajar. Oleh karena itu, perlu diketahui kesulitan siswa dan faktor yang menyebabkan siswa mengalami kesulitan dalam menyelesaikan soal-soal UN serta tingkat selfefficacy siswa dalam menyelesaikan soal-soal tersebut.

Kesulitan siswa dalam menyelesaikan soal Ujian Nasional matematika dimungkinkan terjadi karena siswa kurang menguasai materi matematika dan kurang memahami objek matematika dari pembelajaran matematika. Ahli belajar Gagne (Bell, 1981, p. 108) membagi objek-objek matematika yaitu materi yang dipelajari siswa menjadi objek langsung dan objek tidak langsung. Objek langsungnya adalah fakta, keterampilan, konsep, dan prinsip. Kurang lebih $6 \%$ pada setiap kelas matematika terdapat siswa yang memiliki kesulitan matematika, meliputi kesulitan prosedural dan kesulitan yang berkaitan dengan fakta matematika (Byrnes, 2008 , p. 287). Hal ini berarti, siswa harus mempelajari fakta dan mampu menggunakan prosedur sehingga secara otomatis menjadi kebiasaan untuk menyelesaikan masalah matematika. Kesulitan matematika dapat dikategorikan menjadi tiga jenis, yaitu: (1) kesulitan dalam menggunakan konsep, (2) kesulitan dalam menggunakan prinsip, dan (3) kesulitan dalam memecahkan masalah verbal (Cooney, Davis, \& Henderson, 1983, pp. 216-231).

Kesulitan siswa dalam menyelesaikan soal matematika tidak terlepas dari hambatan dan kendala yang menyebabkan siswa mengalami kesulitan. Salah satu penyebab kesulitan siswa dalam menyelesaikan persoalan matematika adalah kesulitan siswa membaca permasalahan matematika. Siswa cenderung bisa membaca langsung materi dari buku, namun tidak mampu memahami apa yang dibacanya (Bell, 1981, p. 402). Untuk mengetahui kesulitan siswa dan faktor penyebabnya difokuskan pada hal-hal yang disebabkan oleh kesalahankesalahan akibat dari kesulitan dalam menggunakan fakta, keterampilan, memahami konsep dan menerapkan prinsip (Rumasoreng \& Sugiman, 2014, p. 23). Cara terbaik mengidentifikasi penyebab kesulitan siswa adalah meminta siswa membaca permasalahan matema- tika dengan keras lalu meminta siswa menginterpretasikan per kalimat (Bell, 1981, p. 408).

Kemampuan siswa dalam membaca dan menginterpretasikan permasalahan matematika erat kaitannya dengan keyakinan siswa terhadap kamampuan diri sendiri untuk dapat menemukan solusi dari setiap persoalan matematika. Keyakinan seseorang terhadap kemampuan mereka dalam mengatur dan menjalankan program tindakan yang diperlukan untuk menghasilkan pencapaian yang diberikan disebut self-efficacy (Bandura, 1997, p. 3). Siswa yang memiliki selfefficacy yang tinggi akan lebih siap dalam menghadapi berbagai situasi dan mampu menghasilkan hal-hal positif dalam hidupnya.

Berdasarkan hasil wawancara dengan beberapa guru matematika di Kabupaten Ngada diperoleh informasi bahwa self-efficacy siswa terhadap penyelesaian tugas-tugas dalam mata pelajaran matematika masih rendah. Siswa cenderung menghindari soal-soal matematika dengan tingkat kesukaran yang tinggi. Siswa beranggapan bahwa mereka tidak dapat menyelesaikan soal-soal matematika yang diberikan apalagi bila soal yang diberikan memiliki tingkat kesukaran yang tinggi.

Self-efficacy memungkinkan siswa memperoleh prestasi akademis yang memuaskan. Pencapaian prestasi akademis tersebut bergantung dari tinggi atau rendahnya self-efficacy yang dimiliki siswa dalam menyelesaikan tugas berdasarkan tingkat kesulitan yang diberikan. Siswa dengan self-efficacy yang tinggi cenderung tertarik dalam mengerjakan soal dengan tingkat kesulitan yang diberikan dan ketika ada yang salah mencoba untuk mengerjakan kembali, sedangkan siswa dengan self-efficacy rendah cenderung menghindari usaha untuk menyelesaikan soal yang diberikan, apalagi jika tingkat kesulitan semakin kompleks (Schunk, 2012, p. 147). Tinggi rendahnya self-efficacy dapat diukur menggunakan skala yang dibagi menjadi tiga dimensi yaitu level, strength, dan generality untuk berbagai aktivitas dan konteks (Bandura, 1995, p. 203). Level mengacu kepada bagaimana seseorang dapat menyelesaikan tugas-tugas berdasarkan tingkat kesulitan yang semakin kompleks. Generality mengacu kepada bagaimana menggunakan self-efficacy yang dimiliki untuk diterapkan pada situasi lain. Strength mengacu pada bagaimana tingkat keyakinan yang dimiliki dapat menyelesaikan tugas yang diberikan.

Tujuan yang ingin dicapai dalam penelitian ini adalah untuk mendeskripsikan jenis, letak 
dan faktor penyebab kesulitan siswa SMA di Kabupaten Ngada dalam menyelesaikan soal model Ujian Nasional matematika serta mendeskripsikan tingkat self-efficacy siswa dalam menyelesaikan soal-soal tersebut. Hasil penelitian ini diharapkan dapat memberikan manfaat kepada (a) siswa, sebagai acuan dalam mempersiapkan diri menghadapi Ujian Nasional, (b) guru, sebagai bahan masukan untuk mengevaluasi kegiatan pembelajaran matematika dan memperbaiki strategi pembelajaran yang digunakan untuk membelajarkan materi matematika yang sulit dan (c) sekolah, sebagai bahan masukan dalam rangka meningkatkan mutu kelulusan di tahun berikutnya.

\section{METODE}

Jenis penelitian ini adalah penelitian survei dengan pendekatan kuantitatif dan kualitatif karena peneliti menginginkan informasi untuk mendeskripsikan kesulitan siswa dalam menyelesaikan soal model Ujian Nasional matematika dan self-efficacy siswa SMA di Kabupaten Ngada. Ditinjau dari pendekatan analisisnya, penelitian ini terbagi atas dua, yaitu: (1) pendekatan kuantitatif digunakan untuk menentukan jenis dan letak kesulitan siswa dalam menyelesaikan soal model Ujian Nasional matematika, memilih subjek penelitian yang mewakili sampel untuk diwawancarai, menentukan tingkat self-efficacy siswa serta menghitung persentase keterlaksanaan proses pembelajaran, dan (2) pendekatan kualitatif digunakan untuk mendeskripsikan faktor penyebab kesulitan siswa berdasarkan hasil wawancara.

Penelitian ini dilaksanakan di Kabupaten Ngada propinsi Nusa Tenggara Timur. Pengambilan data dilakukan pada 4 SMA kelas XI IPA dan dimulai tanggal 1 Februari 2016 sampai dengan 1 Maret 2016.

Populasi penelitian ini adalah seluruh siswa SMA kelas XI pada 10 sekolah di Kabupaten Ngada dengan siswa sebanyak 1816, karena jumlah populasi siswa yang sangat besar maka perlu diambil sampel penelitian. Teknik pengambilan sampel yang digunakan adalah stratified proportional random sampling atau sampel acak proporsional berstrata. Pengambilan sampel dalam penelitian ini dilakukan dengan mengelompokkan sekolah menjadi tiga kategori yaitu: (1) strata tinggi, untuk sekolah dengan nilai akreditasi A, (2) strata sedang, untuk sekolah dengan nilai akreditasi B, dan (3) strata rendah, untuk sekolah yang tidak/belum terakreditasi. Berdasarkan kategori tersebut di- peroleh 3 sekolah berkategori tinggi, 4 sekolah berkategori sedang dan 3 sekolah berkategori rendah. Selanjutnya ditentukan ukuran sampel minimal dengan menggunakan rumus populasi (Riduwan, 2006, p. 65) sebagai berikut:

$$
n=\frac{N}{N d^{2}+1}
$$

Keterangan:

$$
\begin{aligned}
& n=\text { ukuran sampel } \\
& N=\text { banyaknya siswa } \\
& d^{2}=\text { tingkat prestasi }
\end{aligned}
$$

Sampel minimal dari populasi dalam penelitian ini (menggunakan tingkat presisi 10\%) yaitu:

$$
n=\frac{1816}{1816(0,1)^{2}+1}=94,78 \approx 95
$$

Jadi, ukuran sampel minimalnya yaitu sebesar 95.

Peneliti memperkirakan jumlah siswa dalam satu kelas sekitar 20-25 siswa sehingga terdapat minimal 4 kelas yang akan diambil dalam penelitian ini. Dengan demikian, dalam penelitian ini akan diambil 4 sekolah dari 10 sekolah yang ada di Kabupaten Ngada.

Teknik sampling proporsional (proportional sampling) digunakan untuk menentukan sampel secara proporsional untuk setiap strata. Dari 10 sekolah di Kabupaten Ngada, terdapat 3 sekolah yang berada pada strata tinggi, 4 sekolah berada pada strata sedang, dan 3 sekolah berada pada strata rendah. Karena ada 4 sekolah yang akan dipilih, maka banyak sekolah yang akan diambil untuk setiap strata diperoleh dengan cara sebagai berikut:

$$
\begin{aligned}
\text { Strata Tinggi } & =(3 / 10) \times 4=1,2 \approx 1 \\
\text { Strata Sedang } & =(4 / 10) \times 4=1,6 \approx 2 \\
\text { Strata Rendah } & =(3 / 10) \times 4=1,2 \approx 1
\end{aligned}
$$

Dengan demikian 4 sekolah yang dipilih berdasarkan strata yaitu 1 sekolah dari strata tinggi, 2 sekolah dari strata sedang, dan 1 sekolah dari strata rendah. Selanjutnya dilakukan pengambilan sekolah secara acak (random sampling) untuk setiap strata, sehingga 4 sekolah yang diambil secara acak disebut sebagai sampel acak proporsional (stratified proportional random sampling).

Instrumen dalam penelitian ini adalah tes diagnostik matematika berbentuk soal uraian sebanyak 7 butir soal yang memiliki kompetensi soal dengan daya serap rendah pada Ujian Nasional tahun pelajaran 2014/2015, 35 item angket self-efficacy siswa, 17 item observasi 
Jurnal Riset Pendidikan Matematika, 5 (1), 2018 - 86

Maria Rosadalima Wasida, H. Hartono

keterlaksanaan proses pembelajaran dan pedoman wawancara.

Tabel 2. Daftar Sekolah yang Menjadi Sampel Penelitian

\begin{tabular}{cccc}
\hline No. & Nama Sekolah & Strata & Banyak Subjek \\
\hline 1. & SMA A & Tinggi & 20 \\
2. & SMA B & Sedang & 29 \\
3. & SMA C & Sedang & 23 \\
4. & SMA D & Rendah & 23 \\
& Jumlah & & 95 \\
\hline
\end{tabular}

Tes diagnostik digunakan untuk mendiagnosis kesulitan siswa dalam menyelesaikan soal model Ujian Nasional matematika. Tes diagnostik yang digunakan dalam penelitian ini berupa soal-soal model Ujian Nasional tahun pelajaran 2014/2015 yang telah dimodifikasi oleh peneliti. Tes diberikan kepada siswa dengan alokasi waktu 3 x 40 menit pada masingmasing sekolah.

Angket yang digunakan adalah angket self-efficacy yang dirancang untuk memperoleh informasi mengenai tingkat self-efficacy siswa dalam menyelesaikan soal model UN matematika. Angket self-efficacy siswa memuat pernyataan yang terdiri atas 35 item dengan menggunakan skala Likert. Ada 30 item dengan menggunakan skala Likert selalu, sering, kadangkadang, jarang dan tidak pernah; dan ada 5 item dengan skala Likert sangat setuju, setuju, raguragu, tidak setuju, dan sangat tidak setuju. Penskoran untuk pernyataan positif yaitu lima untuk respon selalu dan sangat setuju, empat untuk respon sering dan setuju, tiga untuk respon kadang-kadang dan ragu-ragu, dua untuk respon jarang dan tidak setuju, satu untuk respon tidak pernah dan sangat tidak setuju. Penskoran untuk respon negatif, yaitu lima untuk respon tidak pernah dan sangat tidak setuju, empat untuk respon jarang dan tidak setuju, tiga untuk respon kadang-kadang dan ragu-ragu, dua untuk respon sering dan setuju, satu untuk respon selalu dan sangat setuju.

Wawancara yang dilakukan adalah wawancara mendalam kepada unit subjek penelitian. Unit subjek penelitian ditentukan berdasarkan perolehan hasil tes diagnostik dengan ketentuan siswa yang memperoleh nilai tes diagnostik di bawah KKM. Dari setiap sekolah dipilih 2 siswa yang mengalami kesulitan. Kedelapan subjek penelitian diwawancara secara mendalam untuk mempertegas jenis dan letak kesulitan, dan memperoleh informasi rinci mengenai faktor penyebab kesulitan menyelesaikan soal model Ujian Nasional matematika.
Observasi dalam penelitian ini dilakukan secara langsung oleh peneliti dengan menggunakan lembar observasi proses pembelajaran. Lembar observasi terdiri atas 17 item dengan skor 0 jika item tersebut tidak terlaksana dan skor 1 jika item tersebut terlaksana. Observasi dilakukan kepada guru dan siswa selama proses pembelajaran dengan alokasi waktu 2 x 45 menit pada masing-masing sekolah.

Data yang diperoleh kemudian dianalisis secara kuantitatif-kualitatif. Langkah-langkah analisis data kuantitatif yaitu: (a) Memberikan dan memeriksa hasil angket self-efficacy siswa; (b) Memberikan dan memeriksa hasil tes diagnostik (benar, benar tapi kurang lengkap, salah mengerjakan, tidak selesai, atau tidak mengerjakan); (c) Melaksanakan observasi dan menghitung persentase keterlaksanaan total dari masing-masing item pengamatan; (d) Menganalisis hasil observasi, angket dan tes berdasarkan indikator-indikator yang telah ditetapkan; (e) Mengidentifikasi siswa yang mengalami kesulitan dalam menyelesaikan soal model Ujian Nasional matematika; (f) Mengidentifikasi selfefficacy siswa berdasarkan kriteria sangat tinggi, tinggi, sedang, rendah dan sangat rendah; (g) Menduga jenis kesulitan siswa dalam menyelesaikan soal model Ujian Nasional matematika; (h) Mengelompokkan jenis kesulitan yang ditemukan pada saat siswa menyelesaikan soal menjadi 4 jenis kesulitan; (i) Menduga letak kesulitan siswa dalam menyelesaikan soal model Ujian Nasional matematika.

Analisis data kualitatif dilakukan untuk menganalisis hasil wawancara. Analisis kualitatif menggunakan model Miles dan Hiberman yang terdiri atas 3 tahap yaitu: reduksi data, penyajian data dan penarikan kesimpulan. Berdasarkan analisis kuantitatif dan kualitatif tersebut, maka diadakan penafsiran data. Setiap hasil analisis data ditafsirkan untuk mendapatkan suatu kesimpulan penelitian.

\section{HASIL DAN PEMBAHASAN}

Data yang diperoleh dalam penelitian ini terdiri atas dua jenis data, yaitu data kuantitatif dan data kualitatif. Berdasarkan analisis data kuantitatif dan kualitatif, akan dideskripsikan semua data yang diperoleh melalui observasi pembelajaran, angket self-efficacy, tes diagnostik dan wawancara mendalam tentang kesulitan menyelesaikan soal model Ujian Nasional matematika. Pendeskripsian data akan difokuskan pada jenis, letak, dan faktor penyebab kesulitan 
siswa dalam menyelesaikan soal model Ujian Nasional matematika dan self-efficacy siswa.

Tabel 3. Persentase Keterlaksanaan Proses Pembelajaran

\begin{tabular}{ccccc}
\hline \multirow{2}{*}{ Item } & \multicolumn{3}{c}{ Strata } & \multirow{2}{*}{ Total } \\
\cline { 2 - 4 } & Tinggi & Sedang & Rendah & \\
\hline KS & 66,7 & 33,3 & 33,3 & 41,7 \\
MP & 0 & 0 & 0 & 0 \\
AS & 83,3 & 66,7 & 50 & 66,7 \\
PG & 80 & 40 & 60 & 55 \\
Total & 64,7 & 41,2 & 41,2 & 47,1 \\
\hline
\end{tabular}

Tabel 3 menunjukkan bahwa secara keseluruhan persentase keterlaksanaan proses pembelajaran hanya mencapai $47,1 \%$. Persentase keterlaksanaan item kesiapan siswa (KS) untuk strata tinggi sebesar $66,7 \%$; strata sedang dan strata rendah sebesar $33,3 \%$. Persentase keterlaksanaan item metode pembelajaran (MP) untuk strata tinggi, strata sedang dan strata rendah sebesar $0 \%$. Persentase keterlaksanaan item keaktifan siswa (AS) untuk strata tinggi sebesar $83,3 \%$; strata sedang sebesar $66,7 \%$ dan strata rendah sebesar 50\%. Persentase keterlaksanaan item peranan guru (PG) dalam pembelajaran untuk strata tinggi sebesar $80 \%$, strata sedang sebesar $40 \%$ dan strata rendah sebesar $60 \%$. Sebagian besar keterlaksanaan item proses pembelajaran pada setiap strata kurang dari $75 \%$, bahkan ada item pengamatan yang tidak terlaksana yaitu pada metode yang digunakan guru dalam pembelajaran. Dengan demikian, kesiapan siswa, metode pembelajaran, peranan guru dan keaktifan siswa yang diamati dalam proses pembelajaran dapat dijadikan sebagai informasi awal berkaitan dengan faktor kesulitan siswa dalam menyelesaikan soal matematika.

Informasi self-efficacy siswa pada tiap strata dalam menyelesaikan soal model Ujian Nasional matematika disajikan pada Tabel 4.

Tabel 4. Deskripsi Data Self-Efficacy Siswa

\begin{tabular}{lcccc}
\hline \multirow{2}{*}{\multicolumn{1}{c}{ Deskripsi }} & \multicolumn{3}{c}{ Strata } & \multirow{2}{*}{ Total } \\
\cline { 2 - 5 } & Tinggi Sedang & Rendah & \\
\hline Rata-rata & 127,5 & 111,1 & 107,5 & 115,4 \\
Standar deviasi & 13,2 & 17,1 & 10,8 & 12,6 \\
Skor maksimal & 175 & 175 & 175 & 175 \\
Skor minimal & 35 & 35 & 35 & 35 \\
Skor tertinggi siswa & 152 & 146 & 127 & 152 \\
Skor terendah siswa & 102 & 71 & 88 & 71 \\
\hline
\end{tabular}

Tabel 4 menunjukkan bahwa rata-rata skor self-efficacy siswa pada strata tinggi, strata sedang dan strata rendah berbeda-beda. Strata tinggi memiliki rata-rata self-efficacy dalam kriteria tinggi yaitu sebesar 127,5. Sedangkan strata sedang dan strata rendah memiliki ratarata self-efficacy dalam kriteria sedang secara berturut-turut sebesar 111,1 dan 107,5. Secara keseluruhan rata-rata skor self-efficacy siswa berada dalam kriteria sedang yaitu sebesar 115,4. Pada strata tinggi, strata sedang dan strata rendah, skor tertinggi siswa berturut-turut sebesar 152, 146, dan 127. Sedangkan skor terendah siswa berturut-turut sebesar 102, 71 dan 88 .

Tabel 5. Frekuensi Self-Efficacy Siswa dalam Menyelesaikan Soal Model UN Matematika

\begin{tabular}{lccccc}
\hline \multirow{2}{*}{ Kriteria } & \multicolumn{5}{c}{ Soal Model UN } \\
\cline { 2 - 6 } & $\mathbf{1}$ & $\mathbf{2}$ & $\mathbf{3}$ & $\mathbf{4}$ & $\mathbf{5}$ \\
\hline Sangat tinggi & 5 & 20 & 40 & 25 & 16 \\
Tinggi & 19 & 36 & 30 & 31 & 18 \\
Sedang & 67 & 35 & 21 & 35 & 53 \\
Rendah & 4 & 4 & 3 & 3 & 6 \\
Sangat rendah & 0 & 0 & 1 & 1 & 2 \\
\hline
\end{tabular}

Tabel 5 menunjukkan frekuensi selfefficacy dari 95 siswa dalam menyelesaikan soal model Ujian Nasional matematika pada setiap kriteria self-efficacy. Pada kriteria sangat tinggi, frekuensi self-efficacy siswa terbanyak adalah dalam menyelesaikan soal model UN 3 (ukuran letak data) yaitu 40 siswa. Pada kriteria tinggi, frekuensi self-efficacy siswa terbanyak adalah dalam menyelesaikan soal model UN 2 (peluang) yaitu 36 siswa. Pada kriteria sedang, frekuensi self-efficacy siswa terbanyak adalah dalam menyelesaikan soal model UN 1 (lingkaran) yaitu 67 siswa. Sedangkan pada kriteria rendah dan sangat rendah, frekuensi self-efficacy siswa terbanyak adalah dalam menyelesaikan soal model UN 5 (trigonometri) secara berturutturut yaitu 6 siswa dan 2 siswa. Hal ini berarti bahwa sebagian besar siswa SMA di Kabupaten Ngada memiliki self-efficacy yang berada pada kriteria sedang dalam menyelesaikan soal model UN matematika.

Tabel 6. Frekuensi Hasil Jawaban Siswa pada Setiap Strata

\begin{tabular}{ccccc}
\hline \multirow{2}{*}{ Jawaban } & \multicolumn{3}{c}{ Strata } & \multirow{2}{*}{ Total } \\
\cline { 2 - 4 } & Tinggi & Sedang & Rendah & \\
\hline MB & 4 & 5 & 2 & 11 \\
BKL & 34 & 22 & 6 & 62 \\
TSM & 11 & 40 & 18 & 69 \\
SM & 88 & 253 & 107 & 449 \\
TM & 3 & 44 & 28 & 74 \\
Total & 140 & 364 & 161 & 665 \\
\hline
\end{tabular}

Tabel 6 menunjukkan bahwa dari jawaban 95 siswa, frekuensi hasil jawaban siswa yang menjawab benar (MB) yaitu ada 4 hasil jawaban pada strata tinggi, 5 hasil jawaban pada strata 
sedang dan 2 hasil jawaban pada strata rendah. Frekuensi hasil jawaban siswa yang menjawab benar tapi kurang lengkap (BKL) yaitu ada 34 hasil jawaban pada strata tinggi, 22 hasil jawaban pada strata sedang dan 6 hasil jawaban pada strata rendah. Frekuensi hasil jawaban siswa yang tidak selesai mengerjakan (TSM) yaitu ada 11 hasil jawaban pada strata tinggi, 40 hasil jawaban pada strata sedang dan 18 hasil jawaban pada strata rendah. Frekuensi hasil jawaban siswa yang salah mengerjakan (SM) yaitu ada 88 hasil jawaban pada strata tinggi, 253 hasil jawaban pada strata sedang dan 107 hasil jawaban pada strata rendah. Frekuensi hasil jawaban siswa yang tidak mengerjakan (TM) yaitu ada 3 hasil jawaban pada strata tinggi, 44 hasil jawaban pada strata sedang dan 28 hasil jawaban pada strata rendah. Secara keseluruhan, frekuensi hasil jawaban siswa terbanyak adalah salah mengerjakan yaitu sebanyak 449 hasil jawaban.

Informasi mengenai frekuensi hasil jawaban siswa pada tiap butir soal dari 95 siswa disajikan pada Tabel 7.

Tabel 7. Frekuensi Hasil Jawaban Siswa pada Tiap Butir Soal

\begin{tabular}{cccccc}
\hline \multirow{2}{*}{ Soal } & \multicolumn{5}{c}{ Jawaban Siswa } \\
\cline { 2 - 6 } & MB & BKL & TSM & SM & TM \\
\hline 1 & 0 & 0 & 20 & 62 & 13 \\
2 & 0 & 9 & 4 & 73 & 9 \\
3 & 1 & 19 & 4 & 69 & 2 \\
4 & 1 & 10 & 8 & 60 & 16 \\
5 & 1 & 9 & 2 & 70 & 13 \\
6 & 0 & 4 & 9 & 70 & 12 \\
7 & 8 & 11 & 22 & 45 & 9 \\
Total & 11 & 62 & 69 & 449 & 74 \\
\hline
\end{tabular}

Tabel 7 menunjukkan frekuensi hasil jawaban 95 siswa pada tiap butir soal. Pada butir soal 1 sampai butir soal 7, frekuensi hasil jawaban siswa terbanyak adalah salah mengerjakan (SM) yaitu 62 hasil jawaban untuk butir soal 1 (lingkaran), 73 hasil jawaban untuk butir soal 2 (ukuran pemusatan data), 69 hasil jawaban untuk butir soal 3 (ukuran letak data), 60 hasil jawaban untuk butir soal 4 (aturan perkalian), 70 hasil jawaban untuk butir soal 5 (kombinasi) dan butir soal 6 (peluang), serta 45 hasil jawaban untuk butir soal 7 (trigonometri). Sedangkan, frekuensi hasil jawaban siswa paling sedikit adalah menjawab benar (MB) yaitu 0 hasil jawaban untuk butir soal 1, 2 dan 6; 1 hasil jawaban untuk butir soal 3, 4 dan 5; dan 8 hasil jawaban untuk butir soal 7. Secara keseluruhan frekuensi hasil jawaban siswa yang salah mengerjakan lebih banyak jika dibandingkan dengan hasil jawaban yang lain. Artinya, 95 siswa SMA di Kabupaten Ngada mengalami kesulitan dalam menyelesaikan soal model Ujian Nasional matematika.

Selain menunjukkan kesulitan siswa dalam menyelesaikan soal, hasil pekerjaan siswa juga menggambarkan jenis kesulitan siswa dalam menyelesaikan soal model Ujian Nasional berdasarkan tes diagnostik seperti yang disajikan pada Tabel 8 .

Tabel 8. Persentase Jenis Kesulitan Siswa pada Tiap Strata

\begin{tabular}{ccccc}
\hline Jenis & \multicolumn{3}{c}{ Strata } & Total \\
\cline { 2 - 4 } Kesulitan & Tinggi & Sedang & Rendah & \\
\hline F & 77,1 & 80,8 & 78,9 & 79,5 \\
K & 77,1 & 93,1 & 88,8 & 88,7 \\
P & 77,9 & 98,4 & 96,3 & 93,5 \\
T & 80,0 & 95,3 & 98,8 & 92,9 \\
Total & 78,0 & 91,9 & 90,7 & 88,7 \\
\hline
\end{tabular}

Tabel 8 menunjukkan persentase jenis kesulitan dari 95 siswa dalam menyelesaikan 7 butir soal model UN berdasarkan tes diagnostik sehingga diperoleh total jawaban untuk setiap jenis kesulitan adalah 665 jawaban. Secara keseluruhan persentase jenis kesulitan tertinggi yang dialami siswa adalah kesulitan dalam menerapkan prinsip (P) yaitu sebesar 93,5\%. Urutan selanjutnya yaitu kesulitan dalam menerapkan keterampilan (T) sebesar 92,9\%; kesulitan dalam memahami konsep (K) sebesar 88,7\% dan kesulitan dalam menyatakan fakta (F) sebesar 79,5\%. Pada jenis kesulitan dalam menyatakan fakta (F), memahami konsep (K) dan menerapkan prinsip $(\mathrm{P})$, siswa pada strata sedang mempunyai persentase kesulitan tertinggi sebesar 80,8\%; 93,1\% dan 98,4\% diikuti oleh strata rendah sebesar $79,8 \% ; 88,8 \%$ dan $96,3 \%$; dan strata tinggi sebesar $77,1 \% ; 77,1 \%$ dan 77,9\%. Sedangkan pada jenis kesulitan dalam menerapkan keterampilan (T), siswa pada strata sedang mempunyai persentase kesulitan tertinggi sebesar 98,8\% diikuti oleh strata sedang sebesar 95,3\% dan strata tinggi sebesar $80 \%$. Hal ini menunjukkan bahwa siswa yang berada pada strata tinggi dan strata rendah paling dominan mengalami kesulitan dalam menerapkan keterampilan sedangkan siswa pada strata sedang paling dominan mengalami kesulitan dalam menerapkan prinsip. Akan tetapi, secara keseluruhan siswa SMA di Kabupaten Ngada paling dominan mengalami kesulitan dalam menerapkan prinsip.

Informasi mengenai persentase jenis kesulitan siswa dalam menyelesaikan soal model 
Ujian Nasional pada tujuh butir soal tes diagnostik untuk setiap jenis kesulitan disajikan pada Tabel 9.

Tabel 9. Persentase Jenis Kesulitan Siswa pada Tiap Butir Soal

\begin{tabular}{|c|c|c|c|c|c|}
\hline \multirow{2}{*}{ Soal } & \multicolumn{4}{|c|}{ Jenis Kesulitan } & \multirow{2}{*}{ Total } \\
\hline & $\mathbf{F}$ & $\mathbf{K}$ & $\mathbf{P}$ & $\mathbf{T}$ & \\
\hline 1 & 93,7 & 88,4 & 98,9 & 100 & 95,3 \\
\hline 2 & 89,5 & 86,3 & 96,8 & 94,7 & 91,8 \\
\hline 3 & 90,5 & 76,8 & 92,6 & 86,3 & 86,6 \\
\hline 4 & 60,0 & 93,7 & 90,5 & 90,5 & 83,7 \\
\hline 5 & 78,9 & 98,9 & 98,9 & 91,6 & 92,1 \\
\hline 6 & 83,2 & 95,8 & 94,7 & 96,8 & 92,6 \\
\hline 7 & 61,1 & 81,1 & 82,1 & 90,5 & 78,7 \\
\hline
\end{tabular}

Tabel 9 menunjukkan persentase jenis kesulitan pada tiap butir soal yang diselesaikan oleh 95 siswa untuk 4 jenis kesulitan sehingga diperoleh total jenis kesulitan untuk setiap butir soal adalah 380 kesulitan. Persentase jenis kesulitan siswa tertinggi dalam menyelesaikan soal model Ujian Nasional yaitu pada penyelesaian butir soal 1 (lingkaran) sebesar 95,3\% dan persentase terendah pada penyelesaian butir soal 7 (trigonometri) sebesar 78,7\%. Pada penyelesaian butir soal 1 (lingkaran), butir soal 6 (peluang) dan butir soal 7 (trigonometri), persentase jenis kesulitan siswa tertinggi adalah kesulitan dalam menerapkan keterampilan (T) masingmasing sebesar $100 \%$; 96,8\% dan 90,5\%. Pada butir soal 2 (ukuran pemusatan data) dan butir soal 3 (ukuran letak data), persentase jenis kesulitan siswa tertinggi adalah kesulitan dalam menerapkan prinsip (P) masing-masing sebesar 96,8\% dan 92,6\%. Pada butir soal 4 (aturan perkalian), persentase jenis kesulitan siswa tertinggi adalah kesulitan dalam memahami konsep (K) sebesar 93,7\%. Sedangkan pada butir soal 5 (kombinasi), persentase jenis kesulitan siswa tertinggi adalah kesulitan dalam memahami konsep $(\mathrm{K})$ dan menerapkan prinsip $(\mathrm{P})$ yaitu sebesar 98,9\%. Hal ini berarti bahwa siswa SMA di Kabupaten Ngada mengalami kesulitan dalam menyelesaikan soal model Ujian Nasional matematika untuk setiap jenis kesulitan.

Pada penyelesaian soal model Ujian Nasional matematika berdasarkan tes diagnostik, dapat diperoleh informasi mengenai letak kesulitan. Letak kesulitan terkait fakta yaitu: kesulitan dalam menentukan apa yang diketahui (F1) dan apa yang ditanya (F2). Letak kesulitan terkait konsep yaitu: kesulitan dalam menentukan rumus (K1) dan sistematika penyelesaian (K2). Letak kesulitan terkait prinsip yaitu: kesulitan dalam menentukan hubungan antar konsep
(P1) dan hubungan antar fakta dan konsep (P2). Letak kesulitan terkait keterampilan yaitu: kesulitan dalam menyelesaikan operasi dasar matematika (T1) dan menentukan jawaban akhir (T2).

Tabel 10. Persentase Letak Kesulitan Siswa pada Tiap Strata

\begin{tabular}{ccccc}
\hline Letak & \multicolumn{3}{c}{ Strata } & \multirow{2}{*}{ Total } \\
\cline { 2 - 4 } Kesulitan & Tinggi & Sedang & Rendah & \\
\hline F1 & 74,3 & 78,6 & 77 & 77,3 \\
F2 & 43,6 & 47,3 & 38,5 & 44,4 \\
K1 & 65 & 71,4 & 77,6 & 71,6 \\
K2 & 60,7 & 90,4 & 85,7 & 83,0 \\
P1 & 74,3 & 97,5 & 95 & 92,0 \\
P2 & 69,3 & 94 & 95 & 89,0 \\
T1 & 72,1 & 92,3 & 95,7 & 88,9 \\
T2 & 77,9 & 94,5 & 98,1 & 91,9 \\
\hline
\end{tabular}

Tabel 10 menunjukkan persentase letak kesulitan dari 95 siswa dalam menyelesaikan 7 butir soal model UN berdasarkan tes diagnostik sehingga diperoleh total jawaban untuk setiap letak kesulitan adalah 665 jawaban. Secara keseluruhan persentase letak kesulitan tertinggi yaitu kesulitan dalam menentukan hubungan antar konsep yaitu sebesar 92,0\%. Urutan letak kesulitan selanjutnya yaitu kesulitan dalam menentukan jawaban akhir sebesar 91,9\%; menentukan hubungan antara fakta dan konsep sebesar $89,0 \%$; menyelesaikan operasi dasar matematika sebesar $88,9 \%$; menentukan sistematika penyelesaian sebesar 83,0\%; menentukan apa yang diketahui sebesar 77,3\%; menentukan rumus $71,6 \%$ dan menentukan apa yang ditanya sebesar 44,4\%. Letak kesulitan dalam menentukan apa yang diketahui, sistematika penyelesaian dan hubungan antar konsep, siswa pada strata sedang mempunyai persentase kesulitan tertinggi sebesar 78,6\%; 90,4\% dan 97,5\% diikuti oleh strata rendah sebesar $77 \% ; 85,7 \%$ dan $95 \%$; dan strata tinggi sebesar $74,3 \% ; 60,7 \%$ dan $74,3 \%$. Letak kesulitan dalam menentukan rumus, hubungan antar fakta dan konsep, menyelesaikan operasi dasar matematika dan jawaban akhir, siswa pada strata rendah mempunyai persentase kesulitan tertinggi sebesar 77,6\%; 95\%; $95,7 \%$ dan $98,1 \%$ diikuti oleh strata sedang sebesar $71,4 \% ; 94 \% ; 92,3 \%$ dan $94,5 \%$; dan strata tinggi sebesar $65 \% ; 69,3 \% ; 72,1 \%$ dan $77,9 \%$. Sedangkan letak kesulitan dalam menentukan apa yang ditanya, siswa pada strata sedang mempunyai persentase kesulitan tertinggi sebesar $47,3 \%$ diikuti oleh strata tinggi sebesar $43,6 \%$; dan strata rendah sebesar $38,5 \%$. Hal ini menunjukkan bahwa letak kesulitan siswa paling 
dominan pada strata tinggi dan strata rendah adalah kesulitan menentukan jawaban akhir, sedangkan pada strata sedang adalah kesulitan menentukan hubungan antar konsep. Secara keseluruhan letak kesulitan siswa SMA di Kabupaten Ngada paling dominan yaitu kesulitan menentukan hubungan antar konsep.

Informasi mengenai persentase letak kesulitan siswa SMA di Kabupaten Ngada dalam menyelesaikan soal model Ujian Nasional matematika pada tujuh butir soal tes diagnostik untuk setiap letak kesulitan disajikan pada Tabel 11.

Tabel 11. Persentase Letak Kesalahan Siswa pada Tiap Butir Soal

\begin{tabular}{cccccccc}
\hline Letak & \multicolumn{7}{c}{ Soal } \\
\cline { 2 - 8 } Kesulitan & $\mathbf{1}$ & $\mathbf{2}$ & $\mathbf{3}$ & $\mathbf{4}$ & $\mathbf{5}$ & $\mathbf{6}$ & $\mathbf{7}$ \\
\hline F1 & 92,6 & 87,4 & 87,4 & 54,7 & 76,8 & 81,1 & 61,1 \\
F2 & 73,7 & 23,2 & 40 & 42,1 & 54,7 & 60,0 & 16,8 \\
K1 & 82,1 & 46,3 & 66,3 & 73,7 & 81,1 & 84,2 & 67,4 \\
K2 & 80 & 84,2 & 61,1 & 87,4 & 97,9 & 94,7 & 75,8 \\
P1 & 92,6 & 95,8 & 91,6 & 90,5 & 98,9 & 93,7 & 81,1 \\
P2 & 98,9 & 89,5 & 84,2 & 87,4 & 89,5 & 92,6 & 81,1 \\
T1 & 98,9 & 90,5 & 78,9 & 88,4 & 88,4 & 95,8 & 81,1 \\
T2 & 100 & 93,7 & 86,3 & 85,3 & 91,6 & 96,8 & 89,5 \\
Total & 89,9 & 76,3 & 74,5 & 76,2 & 84,9 & 87,4 & 69,2 \\
\hline
\end{tabular}

Tabel 11 menunjukkan persentase letak kesulitan pada tiap butir soal yang diselesaikan oleh 95 siswa untuk 8 letak kesulitan sehingga diperoleh total letak kesulitan untuk setiap butir soal adalah 760 kesulitan. Pada butir soal 1 (lingkaran), butir soal 6 (peluang) dan butir soal 7 (trigonometri), persentase letak kesulitan tertinggi adalah kesulitan dalam menentukan jawaban akhir secara berturut-turut sebesar $100 \%$; $96,8 \%$ dan $89,5 \%$. Sedangkan, pada butir soal 2 (ukuran pemusatan data), butir soal 3 (ukuran letak data), butir soal 4 (aturan perkalian), dan butir soal 5 (kombinasi), persentase letak kesulitan tertinggi adalah kesulitan dalam menentukan hubungan antar konsep secara berturut-turut sebesar $95,8 \%$; $91,6 \% ; 90,5 \%$ dan $98,9 \%$. Hal ini berarti bahwa siswa SMA di Kabupaten Ngada mengalami kesulitan dalam menyelesaikan soal model Ujian Nasional matematika untuk setiap letak kesulitan dimana kesulitan dalam menentukan hubungan antar konsep merupakan letak kesulitan paling dominan yang dialami siswa. Butir soal 1 mengenai lingkaran merupakan butir soal dengan letak kesulitan paling tinggi untuk diselesaikan siswa SMA di Kabupaten Ngada jika dibandingkan dengan keenam butir soal lainnya.

Setelah jenis dan letak kesulitan siswa diketahui, selanjutnya ditentukan faktor-faktor yang menyebabkan siswa mengalami kesulitan dalam menyelesaikan soal model Ujian Nasional matematika. Faktor-faktor tersebut dapat ditentukan berdasarkan hasil wawancara. Wawancara mendalam dilakukan dengan terlebih dahulu menentukan subjek penelitian dari masing-masing strata yaitu siswa yang memperoleh nilai tes diagnostik kurang dari 65. Dalam tahap ini terpilih delapan subjek penelitian yang mewakili masing-masing sekolah. Kedelapan subjek penelitian tersebut diwawancarai secara mendalam untuk mendapatkan informasi mengenai penyebab kesulitan dalam menyelesaikan soal.

Berdasarkan hasil wawancara, kesulitan siswa dalam menyatakan fakta dikarenakan siswa tidak mampu dan keliru dalam memahami informasi yang ada pada soal. Siswa cenderung menuliskan prinsip dalam mengerjakan soal sebagai apa yang diketahui sehingga salah dalam menentukan apa yang diketahui. Siswa kelihatan bingung ketika peneliti menanyakan mengapa anda menuliskan yang diketahui dan ditanya seperti itu pada pekerjaan anda. Berbagai hal tersebut dibuktikan dengan beberapa ungkapan siswa sebagai berikut: "saya keliru dalam menentukan apa yang diketahui dan ditanya karena tidak mengerti maksud dari soal nomor 1"; "saya bingung untuk menentukan apa yang diketahui karena tidak mengerti histogram yang disajikan".

Kesulitan siswa dalam memahami konsep dikarenakan siswa tidak mampu dalam mengingat rumus dan cara menyelesaikan soal. Siswa cenderung menjawab lupa dan tidak mengetahui rumus sehingga tidak bisa meneruskan ke langkah penyelesaian selanjutnya. Selain itu ada juga siswa yang menjawab keliru dalam menentukan rumus sehingga salah dalam langkah penyelesaian selanjutnya. Berbagai hal tersebut dibuktikan dengan beberapa ungkapan siswa sebagai berikut: "saya tidak menulis rumus karena tidak mengingat rumus kuartil atas untuk menyelesaikan soal"; "saya keliru dalam menentukan rumus karena mengira soal nomor 5 diselesaikan dengan rumus permutasi"; "saya tidak tahu rumus dan cara untuk menyelesaikan soal".

Kesulitan siswa dalam menerapkan prinsip dikarenakan siswa tidak mampu dalam mengaitkan konsep-konsep saat menyelesaikan soal dan keliru dalam menentukan apa yang diketahui sehingga salah dalam menentukan rumus. Selain itu siswa juga menjawab tidak mampu dalam menentukan pola-pola penyelesaian yang tepat saat menyelesaikan soal. Bahkan ada siswa yang menjelaskan tidak mengerja- 


\section{Jurnal Riset Pendidikan Matematika, 5 (1), 2018 - 91}

Maria Rosadalima Wasida, H. Hartono

kan soal karena tidak mengetahui langkah penyelesaian dan tidak memiliki waktu yang cukup untuk menyelesaikan soal. Berbagai hal tersebut dibuktikan dengan beberapa ungkapan siswa sebagai berikut: "saya tidak menyelesaikan butir soal 7 karena waktu untuk mengerjakan soal sudah selesai"; "saya keliru dalam menentukan rumus kuartil atas karena yang saya tulis sebagai yang diketahui adalah $Q_{I} /$ kuartil bawah".

Kesulitan siswa dalam menerapkan keterampilan dikarenakan siswa keliru dalam menyelesaikan operasi aljabar matematika dan tidak kembali menganalisis hasil pekerjaannya ketika akan menyimpulkan jawaban akhir yang diperoleh. Siswa cenderung menjawab bahwa mereka melakukan kekeliruan tersebut karena terburu-buru dalam menyelesaikan soal. Selain itu ada juga siswa yang menjelaskan bahwa mereka tidak sampai pada tahap menyelesaikan operasi dasar matematika maupun menentukan jawaban akhir karena mereka tidak mengetahui rumus dan cara menyelesaikan soal. Berbagai hal tersebut dibuktikan dengan beberapa ungkapan siswa sebagai berikut: "saya tidak mampu menyelesaikan butir soal 1 sampai menemukan jawaban akhir yang benar karena tidak mengetahui rumus dan cara untuk menyelesaikan soal"; "saya keliru dalam mengoperasikan soal nomor 2 karena terburu-buru dalam menyelesaikan soal"; "saya tidak menyimpulkan jawaban akhir yang diperoleh karena tidak yakin memperoleh jawaban yang benar dalam menyelesaikan soal".

Berdasarkan hasil wawancara yang berkaitan dengan self-efficacy dalam menyelesaikan soal model UN matematika, diperoleh informasi bahwa soal nomor 1 sampai dengan 7 adalah soal yang sulit untuk diselesaikan siswa. Berkaitan dengan hal tersebut, semua siswa menjawab tidak yakin dalam menyelesaikannya tetapi mampu menyelesaikan soal-soal tersebut asalkan banyak latihan, belajar dengan sungguhsungguh dan rajin untuk mengulang. Sebagian siswa tidak yakin dalam memperoleh nilai matematika yang memuaskan. Hal ini dikarenakan siswa cenderung untuk menyalin pekerjaan teman jika tidak bisa menyelesaikan soal matematika yang sulit sehingga ketika siswa menyelesaikan soal sendiri siswa cenderung mengalami kesulitan untuk menyelesaikan soal tersebut. Berbagai hal tersebut dibuktikan dengan beberapa ungkapan siswa sebagai berikut: "saya mampu menyelesaikan soal tersebut namun tidak yakin dengan jawaban yang diperoleh"; "saya tidak mampu menyelesaikan soal matematika yang sulit"; "saya sering menyalin pekerjaan teman karena cepat menyerah dan merasa putus asa dalam menyelesaikan soal yang sulit".

Jenis kesulitan siswa SMA di Kabupaten Ngada dalam menyatakan fakta merupakan jenis kesulitan dengan jumlah kesulitan paling sedikit. Pada jenis kesulitan tersebut, siswa SMA di Kabupaten Ngada paling dominan mengalami kesulitan yang terletak pada kesulitan dalam menentukan apa yang diketahui. Kesulitan tersebut dapat dilihat dari hasil pekerjaan siswa di mana siswa cenderung menuliskan prinsip untuk mengerjakan soal sebagai apa yang diketahui (Cooney et al., 1983, p. 222). Siswa mampu membaca semua kata dalam soal, tetapi tidak menguasai pengertian kata-kata tersebut (White, 2005, p. 17). Sedangkan untuk kesulitan dalam menentukan apa yang ditanya, siswa cenderung membaca soal tanpa memahami informasi yang ada pada soal sehingga salah dalam menentukan apa yang ditanya. Siswa kesulitan dalam memahami perintah-perintah dari permasalahan (Nathan, Sarah, Adam, \& Nathan, 2002, p. 4).

Jenis kesulitan siswa SMA di Kabupaten Ngada dalam memahami konsep merupakan jenis kesulitan yang menempati urutan ketiga untuk jenis kesulitan paling banyak dilakukan siswa. Pada jenis kesulitan tersebut, siswa SMA di Kabupaten Ngada paling dominan mengalami kesulitan yang terletak pada kesulitan dalam menentukan sistematika penyelesaian. Kesulitan tersebut dapat dilihat dari hasil pekerjaan siswa di mana siswa tidak mampu menentukan langkah-langkah yang digunakan untuk menyelesaikan soal. Siswa memiliki ingatan yang lemah dalam meneruskan prosedur/langkah pengerjaan matematika (Nathan et al., 2002, p. 3). Selain itu, siswa tidak dapat menangkap konsep dengan benar dalam hal ini siswa telah mengetahui rumus apa yang digunakan tetapi tidak mengetahui dalam konteks apa rumus tersebut harus digunakan (Jihad, 2008, p. 154). Sedangkan untuk kesulitan dalam menentukan rumus, siswa cenderung salah dalam menentukan rumus yang sesuai dengan informasi pada soal. Siswa tidak mampu dalam mengingat rumus-rumus matematika (Nathan et al., 2002, p. 3).

Jenis kesulitan siswa SMA di Kabupaten Ngada dalam menerapkan prinsip merupakan jenis kesulitan dengan jumlah siswa terbanyak. Pada jenis kesulitan tersebut, siswa SMA di Kabupaten Ngada paling dominan mengalami 
kesulitan yang terletak pada kesulitan dalam menentukan hubungan antar konsep. Kesulitan ini dapat dilihat dari hasil pekerjaan siswa di mana siswa tidak mampu mengingat konsep apa saja yang harus digunakan untuk menyelesaikan soal. Siswa lemah dalam memahami konsep dasar yang membentuk suatu prinsip (Cooney et al., 1983, p. 221) dan siswa tidak bisa menangkap konsep dengan benar (Jihad, 2008, p. 154). Artinya, siswa belum sampai ke dalam proses abstraksi sehingga tidak mampu membuat kaitan antar konsep ketika akan menyelesaikan soal. Sedangkan untuk kesulitan dalam menentukan hubungan antara fakta, siswa melakukan kekeliruan dalam menentukan hubungan antara informasi yang diperoleh dari soal dengan prinsip yang harus digunakan dalam menyelesaikan soal. Siswa tidak mampu menentukan hal-hal yang saling berkaitan sehingga tidak mampu mengabstraksi pola-pola (Cooney et al., 1983, p. 222).

Jenis kesulitan siswa SMA di Kabupaten Ngada dalam menerapkan keterampilan merupakan jenis kesulitan yang menempati urutan kedua untuk jenis kesulitan paling banyak dilakukan siswa. Pada jenis kesulitan dalam menerapkan keterampilan, siswa SMA di Kabupaten Ngada paling dominan mengalami kesulitan yang terletak pada kesulitan dalam menentukan jawaban akhir. Kesulitan tersebut dapat dilihat dari hasil pekerjaan siswa di mana sebagian besar siswa tidak menulis jawaban akhir pada bagian kesimpulan dikarenakan lupa menuliskan dan terburu-buru dalam mengerjakan. Siswa telah menemukan solusi atas permasalahan, tetapi tidak menentukan jawaban akhir (White, 2005, p. 17). Kesalahan terjadi akibat ketidakmampuan untuk kembali memeriksa jawaban yang diperoleh (Drews, Dudgeon, Hansen, Lawton, \& Surtees, 2011, p. 11). Sedangkan untuk kesulitan dalam menyelesaikan operasi dasar matematika, dapat dilihat dari kekeliruan yang dilakukan siswa dalam menyelesaikan operasi dasar matematika seperti penjumlahan, pengurangan, perkalian, pembagian dan penarikan akar. Siswa sering melakukan kesalahan berhitung dan sulit bekerja secara teliti dalam prosedur matematis (Byrnes, 2008, p. 287). Siswa telah mengidentifikasi operasi atau pola operasi pada soal, tetapi tidak menyelesaikan operasi tersebut secara tepat (White, 2005, p. 17).

Faktor kesulitan siswa dalam menyelesaikan soal model Ujian Nasional matematika dilihat berdasarkan analisis hasil pekerjaan siswa dalam menyelesaikan soal tes diagnostik, wawancara mendalam dan observasi terhadap proses pembelajaran. Berdasarkan analisis tersebut, faktor kesulitan siswa dalam menyelesaikan soal model Ujian Nasional matematika antara lain: faktor kesulitan siswa dalam mengingat, terlihat dari kecenderungan siswa yang tidak mengingat rumus dan langkah-langkah penyelesaian yang akan digunakan untuk menyelesaikan soal. Faktor kesulitan siswa dalam memahami, terlihat dari pemahaman siswa akan fakta, konsep dan prinsip yang masih kurang sehingga siswa keliru menulis informasi yang ada pada soal dan keliru memilih strategi penyelesaian untuk menyelesaikan soal yang diberikan. Faktor kesulitan siswa dalam menerapkan, terlihat dari kesalahan siswa dalam menerapkan prinsip dan keterampilan dalam menyelesaikan operasi dasar matematika sehingga siswa pun salah dalam memperoleh jawaban akhir. Faktor kesulitan siswa dalam menganalisis, terlihat dari kecenderungan siswa untuk segera membuat kesimpulan tanpa mengecek lagi hasil pekerjaannya. Faktor-faktor kesulitan tersebut sesuai dengan kajian dari Cooney et al. (1983, p. 213) berkaitan dengan faktor intelektual dimana siswa umumnya kurang berhasil dalam menguasai konsep, prinsip, atau algoritma, walaupun telah berusaha mempelajarinya. Siswa yang mengalami kesulitan mengabstraksi, menggeneralisasi, berpikir deduktif dan mengingat konsepkonsep maupun prinsip-prinsip biasanya mengalami kesulitan matematika.

Selain beberapa faktor yang telah dipaparkan, faktor lain yang dapat menyebabkan siswa mengalami kesulitan dalam menyelesaikan soal model Ujian Nasional matematika yaitu: (a) Siswa keliru dalam menyelesaikan soal yang diberikan, (b) Siswa terburu-buru dalam menyelesaikan soal yang diberikan, (c) Siswa cenderung lupa cara untuk menyelesaikan soal yang diberikan, (d) Siswa membutuhkan waktu yang lama untuk menyelesaikan soal, apalagi jika soal yang diberikan termasuk dalam kategori sulit, dan (e) Siswa cepat menyerah saat menyelesaikan soal. Faktor kekeliruan berkaitan dengan kecerobohan, salah tafsir simbol teks, atau hasil dari kesalahpahaman yang dilakukan siswa (Drews et al., 2011, p. 11). Faktor lupa, disebutkan oleh Wenar (Henson \& Eller, 2012, p. 173) sebagai salah satu karakteristik siswa yang berkesulitan dalam memecahkan masalah matematika. Sedangkan faktor siswa yang cepat menyerah saat menyelesaikan soal matematika bersesuaian dengan faktor emosional yang dikemukakan oleh Cooney et al. (1983, p. 212) 
bahwa siswa sering merasa takut, cemas, kuatir, cepat menyerah, tertekan dan sebagainya pada saat memecahkan masalah matematika.

Faktor-faktor kesulitan siswa dalam menyelesaikan soal model Ujian Nasional matematika tidak hanya dilihat dari kemampuan siswa dalam menyelesaikan soal matematika, tetapi juga dilihat dari keterlaksanaan proses pembelajaran matematika. Faktor kesulitan yang berasal dari proses pembelajaran matematika dilihat dari faktor kesiapan siswa, metode guru, peranan guru dan keaktifan siswa selama pembelajaran berlangsung. Faktor-faktor tersebut dikelompokkan oleh (Suryabrata, 2010, p. 233) sebagai faktor internal (motivasi, kesiapan dan keaktifan siswa dalam belajar) dan faktor eksternal penyebab kesulitan siswa dalam belajar (guru dan model pembelajaran). Faktor kesiapan siswa berkaitan dengan faktor anak didik dimana aktivitas belajar yang kurang dan kebiasaan belajar siswa yang kurang baik menjadi penyebab dalam kesulitan siswa sehingga berpengaruh kepada kesiapan siswa, sedangkan faktor guru berkaitan dengan ketidakcakapan guru dalam mendiagnosis kesulitan belajar anak didik (Djamarah, 2011, p. 237).

Berkaitan dengan self-efficacy siswa dalam menyelesaikan soal model Ujian Nasional matematika, secara teoritis siswa yang memiliki self-efficacy tinggi cenderung tidak memiliki kesulitan dalam menyelesaikan soal matematika yang diberikan. Namun, hal tersebut berbeda secara empiris, ketika peneliti melakukan tes diagnostik. Berdasarkan hasil tes diagnostik kebanyakan siswa tidak mampu mengerjakan soal yang diberikan. Hal ini berarti bahwa siswa masih mengalami kesulitan dalam menyelesaikan soal tersebut. Padahal 95 siswa tersebut memiliki rata-rata self-efficacy yang sedang. Seharusnya motivasi dan self-efficacy masingmasing berpengaruh terhadap hasil belajar matematika (Hamdi \& Abadi, 2014, p. 86). Keadaan ini tidak sejalan dengan kajian yang dikemukakan oleh Pajares \& Urdan (2006, p. 339) bahwa keyakinan self-efficacy memberikan dasar untuk memotivasi, bertindak baik dan berprestasi dalam semua bidang kehidupan dan tidak sesuai dengan temuan Liu \& Koirala (2009, p. 9) bahwa self-efficacy dan prestasi matematika memiliki korelasi yang positif.

Jika dilihat dari setiap strata, siswa yang ada di strata tinggi, memiliki rata-rata selfefficacy siswa yang juga berada pada kriteria tinggi. Hal ini sesuai dengan harapan bahwa sekolah yang berstrata tinggi memiliki self- efficacy yang tinggi. Namun, pada kenyataannya siswa pada strata tinggi yang memiliki selfefficacy tinggi, ternyata masih mengalami kesulitan dalam menyelesaikan soal yang diberikan. Siswa yang ada di strata sedang, rata-rata selfefficacy siswa juga berada pada kriteria sedang. Hal ini sesuai dengan harapan bahwa sekolah yang berstrata sedang memiliki self-efficacy yang sedang. Namun, pada kenyataannya siswa pada strata sedang dan memiliki self-efficacy sedang, ternyata masih mengalami kesulitan dalam menyelesaikan soal yang diberikan. Sedangkan siswa yang ada di strata rendah, rata-rata self-efficacy siswa ternyata berada pada kriteria sedang. Hal ini tidak sesuai dengan harapan bahwa sekolah yang berstrata rendah memiliki self-efficacy yang juga rendah. Dalam tes diagnostik kesulitan siswa sudah sesuai harapan bahwa sekolah yang ada di strata rendah akan mengalami kesulitan dalam menyelesaikan soal tes diagnostik yang diberikan.

\section{SIMPULAN DAN SARAN}

\section{Simpulan}

Jenis kesulitan yang dialami oleh siswa SMA di Kabupaten Ngada dalam menyelesaikan soal model Ujian Nasional matematika yaitu kesulitan dalam menyatakan fakta $(79,5 \%)$; kesulitan dalam memahami konsep sebesar $88,7 \%$; kesulitan dalam menerapkan keterampilan $(92,9 \%)$; dan kesulitan dalam menerapkan prinsip $(93,5 \%)$. Letak kesulitan yang dialami oleh siswa yaitu pada menentukan apa yang ditanya $(44,4 \%)$; menentukan rumus $(71,6 \%)$; kesulitan dalam menentukan apa yang diketahui $(77,3 \%)$; menentukan sistematika penyelesaian (83\%); menyelesaikan operasi dasar matematika sebesar $(88,9 \%)$; menentukan hubungan antara fakta dan konsep sebesar (89\%); menentukan jawaban akhir (91,9\%); dan menentukan hubungan antar konsep (92\%). Faktor-faktor yang menyebabkan siswa mengalami kesulitan dalam menyelesaikan soal model Ujian Nasional matematika, diantaranya yaitu: siswa tidak mampu dalam menyelesaikan operasi aljabar matematika, siswa sering lupa rumus dan cara untuk menyelesaikan soal yang diberikan, siswa kurang teliti saat menyelesaikan soal, siswa terburu-buru dalam menyelesaikan soal, siswa cepat menyerah dalam menyelesaikan soal, siswa merasa waktu yang diberikan tidak cukup untuk menyelesaikan soal, kesiapan siswa dalam belajar yang masih kurang, metode pembelajaran yang tidak mendukung keefektifan pembelajaran, 
guru kurang memberikan informasi yang relevan untuk menemukan fakta, konsep, prinsip dan keterampilan, dan siswa kurang terlibat aktif dalam pembelajaran. Rata-rata self-efficacy siswa SMA di Kabupaten Ngada dalam menyelesaikan soal model Ujian Nasional matematika adalah sebesar 115,4 yang berada dalam kriteria sedang.

\section{Saran}

Bagi guru, hendaknya menginformasikan kepada siswa berkaitan dengan jenis dan letak kesulitan siswa dalam menyelesaikan soal model Ujian Nasional matematika. Guru hendaknya memfokuskan pembelajaran pada kemampuan siswa dalam menyelesaikan soal-soal matematika yang berkaitan dengan jenis dan letak kesulitan dengan memberikan informasi yang relevan mengenai fakta, konsep, prinsip dan keterampilan. Selain itu, guru hendaknya menerapkan metode pembelajaran yang mendukung keefektifan pembelajaran sehingga membantu siswa dalam memahami materi yang dipelajari.

\section{DAFTAR PUSTAKA}

Bandura, A. (1995). Self-efficacy in changing societies. Cambridge, MA: Cambridge University Press.

Bandura, A. (1997). Self-efficacy: The exercise of control. New York, N. Y.: Macmillan.

Bell, F. H. (1981). Teaching and learning mathematics (in secondary schools). Des Moines: W.C. Brown Co.

Byrnes, J. P. (2008). Cognitive development and learning in instructional contexts. Boston, MA: Pearson/Allyn and Bacon Publishers.

Cooney, T. J., Davis, E. J., \& Henderson, K. B. (1983). Dynamics of teaching secondary school mathematics. Boston, M.A.: Waveland Pr Inc.

Djamarah, S. B. (2011). Psikologi belajar. Jakarta: Rineka Cipta.

Drews, D., Dudgeon, J., Hansen, A., Lawton, F., \& Surtees, L. (2011). Children's errors in mathematics: Understanding common misconceptions in primary schools. SAGE.

Hamdi, S., \& Abadi, A. M. (2014). Pengaruh motivasi, self-efficacy dan latar belakang pendidikan terhadap prestasi matematika mahasiswa PGSD STKIP-H dan PGMI IAIH. Jurnal Riset Pendidikan
Matematika, $\quad$ 1(1), 77-86. https://doi.org/10.21831/jrpm.v1i1.2666

Henson, K. T., \& Eller, B. F. (2012). Educational psychology for effective teaching. Kendall Hunt.

Jihad, A. (2008). Pengembangan kurikulum matematika. Yogyakarta: Multi Pressindo.

Liu, X., \& Koirala, H. (2009). The effect of mathematics self-efficacy on mathematics achievement of high school students. In NERA Conference Proceedings 2009 (p. 30). Retrieved from https://opencommons.uconn.edu/nera_200 9/30

Mardapi, D. (2017). Pengukuran penilaian dan evaluasi pendidikan. Yogyakarta: Nuha Medika.

Menteri Pendidikan dan Kebudayaan Republik Indonesia. Peraturan Menteri Pendidikan dan Kebudayaan Republik Indonesia nomor 66 tahun 2013 tentang standar penilaian pendidikan (2013). Indonesia.

Menteri Pendidikan dan Kebudayaan Republik Indonesia. Peraturan Menteri Pendidikan dan Kebudayaan Republik Indonesia nomor 59 tahun 2014 tentang Kurikulum 2013 SMA/MA (2014).

Nathan, V., Sarah, L., Adam, L., \& Nathan, S. (2002). Difficulties with maths: What can stand in the way of a students' mathematical development. Misunderstood Minds. Retrieved from http://www.misunderstoodmind/math_skil 1.

National Council of Teacher Mathematics. (2000). Prinsiples and standards for school mathematics. Reston, VA: NCTM.

Pajares, F., \& Urdan, T. C. (2006). Self-efficacy beliefs of adolescents. IAP - Information Age Pub.

Riduwan, M. B. A. (2006). Belajar mudah penelitian untuk guru-karyawan dan peneliti pemula. Bandung: Alfabeta.

Rumasoreng, M. I., \& Sugiman, S. (2014). Analisis kesulitan matematika siswa SMA/MA dalam menyelesaikan soal setara UN di Kabupaten Maluku Tengah. Jurnal Riset Pendidikan Matematika, 1(1), 22-34. https://doi.org/10.21831/jrpm.v1i1.2661

Schunk, D. H. (2012). Learning theories: An educational perspective. Pearson. 


\section{Jurnal Riset Pendidikan Matematika, 5 (1), 2018 - 95}

Maria Rosadalima Wasida, H. Hartono

Suryabrata, S. (2010). Psikologi pendidikan. Jakarta: PT Rajagrafindo.

White, A. L. (2005). Active mathematics in classrooms: Finding out why children make mistakes - and then doing something to help them. Square One: Primary Journal of the Mathematical Association of New South Wales, 15. 